\title{
Article
}

\section{Effect of lead acetate alone and in combination with whole milk (Star ship®) on body growth and liver functions in an experimentally induced lead toxicity in rat}

\author{
Mohammad Usman Gani ${ }^{1 \mathrm{a}}$, Md. Saiful Islam Siddiqui ${ }^{2 \mathrm{a}^{*}}$, Md. Harun-or-Rashid ${ }^{3}$, Kamrul Islam $^{4}$, Sharifunnessa \\ Moonmoon $^{2}$, Shaifuddin Ahmed ${ }^{5}$ and Mahbub Mostofa ${ }^{6}$ \\ ${ }^{1}$ Upazilla Livestock Office, Kotiadi, Kishoregonj, Bangladesh \\ ${ }^{2}$ Sylhet Agricultural University, Sylhet-3100, Bangladesh \\ ${ }^{3}$ Upazilla Livestock Office, Singair, Manikgonj, Bangladesh \\ ${ }^{4}$ Upazilla Livestock Office, Kaligonj, Gazipur, Bangladesh \\ ${ }^{5}$ Upazilla Livestock Office, Kulaura, Moulvibazar, Bangladesh \\ ${ }^{6}$ Department of Pharmacology, Faculty of Veterinary Science, Bangladesh Agricultural University, \\ Mymensingh-2202, Bangladesh
}

${ }^{a}$ Mohammad Usman Gani and Md. Saiful Islam Siddiqui contributed equally to this work

*Corresponding author: Md. Saiful Islam Siddiqui, Sylhet Agricultural University, Sylhet-3100, Bangladesh. Mobile: +8801712220335; E-mail: msisiddiqui2000@yahoo.com

Received: 19 May 2016/Accepted: 13 June 2016/ Published: 30 June 2016

\begin{abstract}
The Effect of lead acetate alone and in combination with whole milk on body weight gain and some biochemical parameters were carried out on a total of 15 (15 days old) male weaning Long- Evans strain rats. The rats were randomly divided into three equal groups, each consisting of five rats. Rats of group A were kept as control (without giving any treatment), group B received lead acetate alone @ 6mg/ml drinking water and group C received lead acetate @ 6mg/ml plus whole milk (Star ship®) $150 \mathrm{mg} / \mathrm{ml}$ drinking water. The result showed that body weight gain of control group per week per rat was found to increase but in treated group B, the body weight gain was found to decrease most significantly $(\mathrm{P}<0.01)$ on day 56 while in group $\mathrm{C}$, body weight was reduced significantly $(\mathrm{P}<0.05)$ on day 56 . The reducing body weight gain was less in group $\mathrm{C}$ than group B. A most significantly $(\mathrm{P}<0.01)$ increased SGOT and SGPT values were observed in Group B but in group $\mathrm{C}$, those count increased significantly $(\mathrm{P}<0.05)$ on day 56 of experiment. From the study it was concluded that treatment with lead acetate at low doses has adverse effects on body growth and liver functions in experimental animals.
\end{abstract}

Keywords: lead acetate; whole milk; body weight; liver function; rat

\section{Introduction}

Lead is one of the major environmental pollutants (toxin) in the modern world whose higher concentrations particularly in industrial zone; adversely affect the vitality and production performance of domestic animals (Kwatra et al., 1986). Lead usually induce adverse effects on the central nervous system as irritating, immunosuppressive, genotoxic, teratogenic, nephrotoxic and other toxic effects on the haematopoietic system. Lead is also known to modify the metabolism of trace elements and nutrients (Levander, 1979). Also, lead administration decreased liver copper level whereas additional dietary copper increased the liver lead level (Bafundo et al., 1984). It was postulated that lead interferes with copper and iron metabolism (Klauder and petering, 1977). Lead is considered as pathogenic factor of atherosclerosis, arterial hypertension and may cause an anemia. Belacy et al., (1996) reported that lead induce inhibition of renal and hepatic transaminase and alkaline phosphates. Several studies have led to reports that lead has effects on glucose utilization at low levels 
resulting in disturbed acetylcholine synthesis and energy metabolism (Yun and Hoger, 2000). On the other hand Gupta et al., 1995 stated that the body attempts to regulate the Pb toxicity by promoting self defense by enhanced production of thiol compounds such as glutathione. The concentration of lead residues in tissues of farm animals depend upon the rout of entering and period of exposure. Most orally ingested lead is deposited in the skeleton (National Academy of Science, 1972). Initially, lead deposited in bone until a possible threshold is reached then it deposited in other tissues especially in the liver and kidneys. The lead particles which ingested or inhalated pass to the blood stream and $82.0 \%$ was excreted in faeces and urine. Only $0.5 \%$ was excreted with the milk and the rest $17.95 \%$ remains and restored in tissues and body organs (Baars et al., 1988). Frangenberg (1986) found that administration of very high dose of lead to animals resulted in highest lead accumulation in the kidney then liver, bone marrow, brain and finally in the heart muscles. The aim of the present study is to show the effect of lead on body growth \& some biochemical parameters related to liver functions in rat and investigate the protective role of whole milk against the adverse effects of lead toxicity.

Lead is one of the major environmental pollutants (toxin) in the modern world whose higher concentrations particularly in industrial zone; adversely affect the vitality and production performance of domestic animals (Kwatra et al., 1986). Lead usually induce adverse effects on the central nervous system as irritating, immunosuppressive, genotoxic, teratogenic, nephrotoxic and other toxic effects on the haematopoietic system. Lead is also known to modify the metabolism of trace elements and nutrients (Levander, 1979). Also, lead administration decreased liver copper level whereas additional dietary copper increased the liver lead level (Bafundo et al., 1984). It was postulated that lead interferes with copper and iron metabolism (Klauder and petering, 1977). Lead is considered as pathogenic factor of atherosclerosis, arterial hypertension and may cause an anemia. Belacy et al., (1996) reported that lead induce inhibition of renal and hepatic transaminase and alkaline phosphates. Several studies have led to reports that lead has effects on glucose utilization at low levels resulting in disturbed acetylcholine synthesis and energy metabolism (Yun and Hoger, 2000). On the other hand Gupta et al., 1995 stated that the body attempts to regulate the Pb toxicity by promoting self defense by enhanced production of thiol compounds such as glutathione. The concentration of lead residues in tissues of farm animals depend upon the rout of entering and period of exposure. Most orally ingested lead is deposited in the skeleton (National Academy of Science, 1972). Initially, lead deposited in bone until a possible threshold is reached then it deposited in other tissues especially in the liver and kidneys. The lead particles which ingested or inhalated pass to the blood stream and $82.0 \%$ was excreted in faeces and urine. Only $0.5 \%$ was excreted with the milk and the rest $17.95 \%$ remains and restored in tissues and body organs (Baars et al., 1988). Frangenberg (1986) found that administration of very high dose of lead to animals resulted in highest lead accumulation in the kidney then liver, bone marrow, brain and finally in the heart muscles. The aim of the present study is to show the effect of lead on body growth \& some biochemical parameters related to liver functions in rat and investigate the protective role of whole milk against the adverse effects of lead toxicity.

\section{Materials and Methods \\ 2.1. Experimental animals}

Fifteen days old male weaning Long Evans rat (Rattus norvegicus) weighing between 182-294 g were purchased from ICDDRB, Dhaka and brought to the Experimental Pharmacology and Toxicology laboratory at Bangladesh Agricultural University (BAU) for the present study. They were housed throughout the entire period of study in Perspex cages with aluminium grid on the bottom fixed on inch a part to facilitate fecal materials and urine in a room maintaining $23 \pm 1^{\circ} \mathrm{C}$. After 06 days of acclimatization animals were segregated on the basis of their age and body weight without significant differences. The rats were fed on standard rat chow ( $15 \mathrm{~g} / \mathrm{rat} / \mathrm{day})$ for 56 days formulated by ICDDRB, Dhaka and supplied fresh water.

\subsection{Experimental chemicals}

Lead acetate 500mg (BDH co.) from Hatkhola market, Dhaka and Whole milk (Starship) from local market were purchased and brought to the laboratory for this study.

\subsection{Experimental design}

A total of 15 (15 days old) male weaning Long Evans rats were used. These rats were randomly divided in to 3 equal groups, and numbered them as group A, B and C. Out of 3 groups, rats of group A was kept as control without giving any treatment, rats of group B received lead acetate alone @ 6mg/ml drinking water and group C received lead acetate @ 6mg/ml plus whole milk (Star ship®) $150 \mathrm{mg} / \mathrm{ml}$ of drinking water. Prior to segregation, initial body weight of each rat was recorded and kept group wise in cages. After administration of lead acetate with drinking water all the rats were kept under close observation for a whole period of study and 
all the parameters (body weight gain or loss, biochemical parameters eg. SGOT and SGPT) were recorded at specific day intervals.

\subsection{Reagents for liver function test}

2.4.1. Determination of SGOT

a. Buffer substrate: (i) Tris buffer $\left(84 \mathrm{mmol} / \mathrm{L} \mathrm{P}^{\mathrm{H}} 7.5\right)$ (ii) L-aspartate $(260 \mathrm{nmol} / \mathrm{L})$

b. Enzyme/ co-enzyme/ $\alpha$-oxoglutarate: (i) $\alpha$-oxoglutarate $(12 \mathrm{mmol} / \mathrm{L}$ ) (ii) $\mathrm{LD} \geq 1.2 \mathrm{U} / \mathrm{ml}$ (iii) $\mathrm{NADH} 0.18$ $\mathrm{mmol} / \mathrm{L}$ (iv) $\mathrm{MDH} \geq 420 \mathrm{U} / \mathrm{L}$

\subsubsection{Determination of SGPT}

a. Buffer substrate: (i) Tris buffer $\left(100 \mathrm{mmol} / \mathrm{L} \mathrm{P}^{\mathrm{H}} 7.5\right)$ (ii) L-alanine $(0.6 \mathrm{~mol} / \mathrm{L})$

b. Enzyme/ co-enzyme/ $\alpha$-oxoglutarate: (i) $\alpha$-oxoglutarate $(15 \mathrm{mmol} / \mathrm{L}$ ) (ii) $\mathrm{LD} \geq 1.2 \mathrm{U} / \mathrm{ml}$ (iii) $\mathrm{NADH} 0.18$ $\mathrm{mmol} / \mathrm{L}$

\subsection{Measurement of body weight}

The body weight of each rat was measured just before starting of treatment and body weight gain or loss was recorded in each 7 days interval up to sacrificing of the animals.

\subsection{Procedures for the collection of blood sample for serum separation}

Blood was collected just before treatment i.e. day 0 and day 56 of treatment directly from tip of the tail of etheranesthetized rat. Immediately after collection blood was transferred to sterile tube containing anticoagulant (4\% sodium citrate solution) at a ratio of 1:10 and used for different hematological parameters immediately after collection.

\subsection{Biochemical study related to liver functions}

Two widely used biochemical test such as SGOT and SGPT were determined by UV method using IFCC used Humalyzer 2000, Human type Germany.

\subsection{Determination of SGOT \& SGPT}

$0.1 \mathrm{ml}$ of serum was mixed with $1.0 \mathrm{ml}$ kit solution 2 enzyme/coenzyme/ $\alpha$-oxoglutarate AL 1205 including buffer substrate with L-aspartate for SGOT and buffer substrate with L-alanine for SGPT determination. The wave length was set at $340 \mathrm{~nm} \mathrm{Hg}, 1 \mathrm{~cm}$ light path cuvette was used and analysis was done at $37^{\circ} \mathrm{C}$. After mixing the cuvette was placed in the Humalyzer 2000. Initial absorbance was read after 1 minute. The final record was made at 1, 2, 3 minutes after initial reading. Absorbance was recorded each time $(0.11$ and 0.16 at $340 \mathrm{~nm} / \mathrm{Hg} 340 \mathrm{~nm})$. First two values for the first 2 minutes were used for the calculation.

Calculation: SGOT concentration: $1746 \mathrm{x}$ absorbance U/1

Calculation: SGPT concentration: $1746 \mathrm{x}$ absorbance U//1

\subsection{Statistical analysis}

The data of the body weight, SGOT and SGPT were analyzed statistically using T- test.

\section{Results and Discussion}

\subsection{Effect on body weight}

The body weight of rats of control group was found to increase but in treated group B the body weight was found to decrease $(-9.99 \%)$ most significantly $(\mathrm{P}<0.01)$ on day 56 while in group $\mathrm{C}$ body weight was reduced $(-$ $5.95 \%)$ significantly $(\mathrm{P}<0.05)$ on day 56 (Table 1$)$. The reducing body weight was less in group $\mathrm{C}$ (lead acetate plus whole milk) than in group B (only lead acetate) most probably due to the positive effect of whole milk supplementation. These observations was in accordance with the result of studies which reported that lead caused reduction in growth rate in experimental animals when fed lead (Ali et al., 2010; Seddik et al., 2010). It has been observed reduction of body weight in lead induced toxicities in rats (Aseth et al., 1995; Teijon et al., 2006). The body weight gain was decreased after treatment with lead in a dose of $400 \mathrm{mg} / \mathrm{kg}$ of the fodder (Szymezak et al., 1983). The body weight loss might be resulting from the interruption of lead acetate in absorption and metabolism of feed nutrients essential for health (Marija et al., 2004). Similar findings were also reported by Ibrahim et al., (2012). 
Table 1. Effects of oral administration of lead acetate alone and in combination with whole milk in drinking water on body weight in rats.

\begin{tabular}{|c|c|c|c|c|c|c|c|c|c|c|c|}
\hline \multirow[t]{2}{*}{ Gr. } & \multirow{2}{*}{$\begin{array}{l}\text { Chemicals } \\
\text { with dose }\end{array}$} & \multirow{2}{*}{$\begin{array}{l}\text { Pretreat- } \\
\text { ment } \\
\text { Day } 0\end{array}$} & \multicolumn{9}{|c|}{ Post treatment } \\
\hline & & & Day 7 & Day 14 & Day 21 & Day 28 & Day 35 & Day 42 & Day 49 & Day 56 & $\begin{array}{l}\% \\
\text { increased/ } \\
\text { decreased }\end{array}$ \\
\hline $\mathrm{A}$ & Control & $254.60 \pm 5.80$ & $259.20 \pm 5.66$ & $262.80 \pm 7.17$ & $268.20 \pm 6.79$ & $272.00 \pm 7.14$ & $277.00 \pm 7.24$ & $278.20 \pm 7.29$ & $280.00 \pm 7.23$ & $285.80 \pm 6.87$ & +12.25 \\
\hline B & $\begin{array}{l}\text { lead acetate } \\
@ 6 \mathrm{mg} / \mathrm{ml} \\
\text { drinking water }\end{array}$ & $240.66 \pm 9.74$ & $242.80 \pm 11.67$ & $245.60 \pm 6.65$ & $252.40 \pm 16.53$ & $253.20 \pm 14.39$ & $245.20 \pm 9.23$ & $240.40 \pm 11.95$ & $230.20 \pm 0.80$ & $218.80 \pm 0.40^{*}$ & -9.99 \\
\hline $\mathrm{C}$ & $\begin{array}{l}\text { lead acetate @ } \\
6 \mathrm{mg} / \mathrm{ml} \text { plus } \\
\text { whole milk } \\
\text { (star ship) } 150 \\
\mathrm{mg} / \mathrm{ml} \text { of } \\
\text { drinking water }\end{array}$ & $243.80 \pm 0.85$ & $247.60 \pm 0.95$ & $228.40 \pm 6.31$ & $273.00 \pm 6.22$ & $245.60 \pm 9.51$ & $236.20 \pm 7.26$ & $235.0 \pm 9.19$ & $232.60 \pm 8.70^{*}$ & $230.10 \pm 0.11^{* *}$ & -5.95 \\
\hline
\end{tabular}

Values above represent the mean \pm SE of 5 rats

* Indicates significant values

** Indicates highly significant values

+ indicates $\%$ increased - indicates $\%$ decreased. 


\subsection{Effect on biochemical parameters related to liver functions}

The activities of SGOT and SGPT were significantly elevated in all treated groups than control. In group B (only lead acetate @ 6mg/ml drinking water) the elevation of SGOT and SGPT were much more higher $(\mathrm{P}<0.01)$ than group C $(\mathrm{P}<0.05)$ (lead acetate @ 6mg/ml plus whole milk (Star ship ${ }) 150 \mathrm{mg} / \mathrm{ml}$ drinking water) (Table-2).

Table 2. Effect of oral administration of lead acetate alone and in combination with whole milk in drinking water on some biochemical parameters such as SGOT/ AST and SGPT/ ALT (U/L at $\left.37^{\circ} \mathrm{C}\right)$ in rats

\begin{tabular}{lllll}
\hline Parameters & Group & Chemicals with dose & Pre-treatment & Post treatment \\
\cline { 3 - 4 } & & & Day 0 & Day 56 \\
\hline SGOT/ AST & A & Control & $216 \pm 0.12$ & $216 \pm 0.25$ \\
& B & $\begin{array}{l}\text { lead acetate @ 6mg/mldrinking water } \\
\text { lead acetate @ 6mg/ml plus whole milk } \\
\text { (star ship) } 150 \mathrm{mg} / \mathrm{ml} \text { of drinking water }\end{array}$ & $214 \pm 0.93$ & $234 \pm 0.15^{* *}$ \\
& $\mathrm{C}$ & Control & $101 \pm 0.52$ & $218 \pm 0.83^{*}$ \\
SGPT/ ALT & A & lead acetate @6mg/mldrinking water & $102 \pm 0.85$ & $104 \pm 0.16$ \\
& B & lead acetate @ 6mg/ml plus whole milk & $103 \pm 0.87$ & $121 \pm 0.15^{* *}$ \\
& C & (star ship) $150 \mathrm{mg} / \mathrm{ml}$ of drinking water & & $107 \pm 0.81^{*}$ \\
\hline
\end{tabular}

\footnotetext{
Values above represent the mean \pm SE of 5 rats

* Indicates significant values $(\mathrm{P}<0.05)$

** Indicates highly significant values $(\mathrm{P}<0.01)$
}

The activities of two enzyme namely serum glutamate pyruvate transaminase (SGPT); recently called as alanine transaminase (ALT) and serum glutamate oxaloacetate transaminase (SGOT); recently called aspartate transaminase (AST) have been widely used to assess the liver functions. ALT was a cytoplasmic enzyme while AST was found in both cytoplasm and mitochondria. SGPT or ALT was found to increase in acute hepatitis (viral or toxic), jaundice, liver cirrhosis. SGOT or AST was found to increase in myocardial infarction and different liver disorders. In the present study the values of SGOT and SGPT were significantly increased at day 56 in all treated groups (B \& C) than in control group A. The present results were agreed by the results of Khan et al., (2008) who reported that the activities of serum AST and ALT were significantly increased in lead exposed rats. Activities of ALT, AST and ALP were significantly increased in rats given daily lead acetate in diet as $500 \mathrm{mg} / \mathrm{kg}$ after 2, 4 and 6 weeks of treatment (Dioka et al., 2004; Othman et al., 2004; Shalan et al., 2005; Al-Wabel et al., 2007; Herman et al., 2009; Mehana et al., 2010; Lynda et al., 2011; Nabil et al., 2012). Increasing of the serum activities of AST and ALT was most likely a consequence of the hepatotoxic effect of lead i.e the occurrence of toxic hepatitis. The lead entering the body by ingestion was delivered to the liver through the portal blood circulation and smaller part of the lead "break the liver barrier" and enters the body circulation. The accumulated lead in the liver can act by directly damaging the hepatocytes primarily by destroying the permeability of the cell membrane, with resultant release of cellular enzymes leading to increase their serum values (Todorvic et al., 2005). Durgut et al. (2008) found that, the increasing serum activities of AST and ALT were associated with liver damage and or cardiac or skeletal muscle damage. Furthermore Nabil et al. (2012) reported that the high plasma AST and ALT activities was accompanied by high liver microsomal membrane fluidity, free radical generation and alteration in the liver tissue. On the other hand, the present results were disagreed by the results of Singh et al. (1994). A possible explanation for such differerence results were the quite different in view of the experimental design and the applied doses of lead, duration of exposure and the way how lead got into the organism. The result of this study was in agreement with the findings found in a study conducted by Hanan et al., (2012) on rats, at a dose of $0.5 \mathrm{~g} / 100 \mathrm{ml}$ drinking water for 2 months, whose dose and the duration of the exposure were almost similar to the present study. The increase was less in group $\mathrm{C}$ than $\mathrm{B}$, the reason was not clear but this might be due to the positive effect of whole milk (star ship) supplementation.

\section{Conclusions}

Treatment with lead acetate at low doses has adverse effects on body growth and liver functions in experimental animals. Therefore, whole milk (star ship) might be helpful to reduce the body burden of lead toxicities. 


\section{Conflict of interest}

None to declare.

\section{References}

Ali MA, MA Awal, M Mostofa, MA Islam and A Ghosh, 2010. Effects of selenium and vitamin B6 with their combination lead acetate induced toxicities in long evan rats. Bangladesh Journal of Veterinary Medicine, 8: $63-73$.

Al-Wabel NA, HM Mousa, OH Omer and AM Abdel-Salam, 2007. Biological evaluation of synbiotic fermented milk against lead acetate contamination in rats. J. Food, Agricul.Environ., 5: 169- 172

Alwaleedi SA, 2015. Haemato-biochemical changes induced by lead intoxication in male and female albino mice. Intl. J. Recent Scient. Res., 6: 3999 -4004.

Aseth J, Jacobsen D, Andersen O and Wickstron E, 1995. Treatment of mercury and lead poisoning with dimercaptosuccinic acid (DMSA) and sodium dimercapto- propanesulfonate (DMPS). Analyst, 12: 853.

Baars AJ, IJ Spierenburg and GJ Graaf, 1988. Chrome lead and cadmium poisoning in farm animals. 2nd annual conference on trace. Substances in environ. Health. St. touis, Missouri 23 - 25 May (1988) Edited by Hemophill, D.D.

Bafundo KW, DH Baker and PR Fitzgerald, 1984. Lead toxicity in the chick as affected by excess copper and zinc and by Eimeria acervulina infection. Poult. Sci; 63: $1594-1603$.

Belacy N, H Shaha, G Edrees and AR EL-Arbagy, 1996. The contribution of heavy metal in kidney dysfunction. J. Union. Arab. Biol., 5 : 147-155.

Dioka CE, OE Orisakwe, FA Adeniyi and SC Meludu, 2004. Liver and renal function tests in artisans occupationally exposed to lead in mechanic village in Nnewi, Nigeria. Intl. J. Environ. Res.Public Health, $1: 21-25$

Durgut R. A, R Gonenci, R Bal, S Celik, M Guzaf, ME Altug and Atesoglu O, 2008. Effect of high dose lead toxication on liver ,kidney, heart, brain and blood rabbits: an experimental study . J. Appl. Biol. SC., 2: 1118.

Frangenberg J, 1986. $\mathrm{Pb}, \mathrm{Cd}, \mathrm{Fe}$ and $\mathrm{Cu}$ in organen Von Krankten Kalbern Zur erlangung des doctor grades beim fachbereich vetrinar medizin lustus liebig. Universtate Gie Ben.

Gupta GS, J Singh and P Parkash, 1995. Renal toxicity after oral administration of lead acetate during pre and post implantation periods: effects on trace metal composition, meta 110 enzymes and glutathione. Pharm. Toxicol., 76: 206-211.

Hanan A, R Azoz and M Raafat 2012: Effect of Lead Toxicity on Cytogenisity, Biochemical Constituents and Tissue Residue with Protective Role of Activated Charcoal and Casein in Male Rats. Australian Journal of Basic and Applied Sciences, 6: 497-509,

Herman DS, M Geraldine and T venkatesh, 2009. Influence of minerals on lead - induced alterations in liver function in rats exposed to long term lead exposure J. Hazard Mate., 166: 1410-1414.

Ibrahim NM, EA Eweis, El-Beltagi H S and Y E Abdel-Mobdy , 2012. Effect of lead acetate toxicity on experimental male albino rat. Asian Pacific Journal of Tropical Biomedicine 2: 41-46.

Khan MSH, M Mostofa, MS Jahan, MA Sayed and Hossain 2008. Effect of garlic and vitamin b-complex in lead acetate induced toxicities in mice. Bangl. J. Vet. Med., 6: 203-210.

Klauder DS and HG Petering, 1977. Anaemia of lead intoxication: a role for copper. J. Nutr., 10: 1779-1785.

Kwatra MS, BS Gill, R Singh and M Singh, 1986. Lead toxicosis in buffaloes and cattle in Punjab. Indian J. Anim. Sci., 56: 412-413.

Levander OA, 1979. Lead toxicity and nutritional deficiencies. Environ. Hlth. Presp., 29: 115-125.

Lynda A, Hamadouche M, Touabti A and Khennouf S, 2011. Effect of longterm exposure to low or moderate lead concentrations on growth lipid profile and liver function in albino rats. Advances in Biological Research, 5: 339-347.

Marija V, M Piasek, M Blanusa, M Saric, D Juresa and K Kostial, 2004. Succimer treatment and calcium supplimentation reduce tissue lead in suckling rats. Journal of Applied Toxicology, 124: 123-128.

Mehana EE, AMA Meki and KM Fazili, 2010. Ameliorated effects of green tea extract on lead induced liver toxicity in rats. Exp. Toxicol. Pathol., 64: 291-295.

National Academy of Sciences, 1972. Lead air borne lead in perspective committee on biologic effects of atmospheric pollutants. Division of Medical Sciences National Academy of Sciences. Washington DC.

Nabil MI, AE Esam, H El-Beltagi and M Y E Abdel, 2012. Effect of lead acetate toxicity on experimental male albino rat. Asian Pacific Journal of Tropical Biomedicine; 2: 41-46. 
Othman AI, S Al Sharawy and MA El- Missiry, 2004. Role of melatonin in ameliorating lead induced haematotoxicity. Pharmacol. Res., 50: 301-307.

Seddik L, TM Bah, A Aoues, M Brnderdour and M Silmani, 2010. Dried leaf extract protects against leadinduced neurotoxicity in Wistar rats. Eur. J. Sci. Res., 42: 139-151.

Singh B, D Dhwan, B Nehru, ML Garg, PC Mangal, B Chand and PN Trhan, 1994. Impact of lead pollution on the status of other trace metals in blood and alterations in hepatic functions. Biol. Trace Elem. Res., 40: 2129.

Shalan MG, MS Mostafa, MM Hassouna, SE Hassab El-Nabi and A El-Refaie, 2005. Amelioration of lead toxicity on rat liver with vitamin $\mathrm{C}$ and silymarin supplements. Toxicol., 206: 1-15.

Szymezak J, Zechalko and J Biernat, 1983. Effect of fodder fat type on blood plasma lipids in rats intoxicated with lead. Bromatol. Chem. Toksykol., 16: 98-94.

Teijon C, R Olmo, D Blanco, A Romero and JM Teijon, 2006. Low doses of lead: effects on reproduction and development in rats. Biol Trace Elem Res., 111: 151-165.

Todorovic T, I Dozic, D Vujanovic, Pejovic and M Marjanovic, 2005. The influence of chronic lead poisoning on the activity of some serum enzymes in rats. Acta Veterinaria, 55: 471-482.

Yun and Hoger, 2000. Effects of low-level lead on glycolyfic enzymes and pyruvate dehydorgenase of rat brain invitro: revevance to sporadic Al zheimers disease? J. Neural. Traism., 107: 355 -368. 